\title{
PCR-RFLP TECHNIQUE FOR SPECIES ORIGIN IDENTIFICATION OF IMPORTED BUFFALO MEAT
}

\author{
Dilger M. Khudir Kamaran M. Taha Azad B. Sabow \\ Department of Animal Resources, College of Agricultural Engineering Sciences, \\ Salahaddin University-Erbil, Kurdistan Region, Iraq. \\ Email:azad1979sabow@yahoo.com
}

\begin{abstract}
The study aimed to identify the species origin of imported buffalo meat from three countries Ukraine, Brazil and India to Erbil using PCR-RFLP technique. The pair of universal cyt b primer was designed to amplify a 359 bp DNA fragment in PCR amplification. Then the amplified fragments were digested with Hinf1 and Rsa I restriction enzymes, achieving a characteristics banding pattern in a $2 \%$ agarose which produced evidence to identify origin meat species. The results presented that digestion of samples with the Hinf1 RE, produced two bands in each (Ukraine and Brazil), (58 and 301) bp while it was showed different bands in Indian buffalo meat $(85,274) \mathrm{bp}$. On the other hand the outcomes in the Rsa I RE were two bands in Ukraine and Brazil $(156,203)$ bp and two bands were obtained in Indian buffalo meat $(106,253) \mathrm{bp}$. The results realized that the Indian buffalo meat species was not acceptable and showed mislabeling products. Thus, the obtained results recommend that the PCR-RFLP technique with HinfI and Rsa I restriction enzymes play an important role to detect the origin meat species, since it is a fast, simple and easily handle technique for detection of meat species.
\end{abstract}

Keywords: Imported buffalo meat; meat products identification; Mt cyt B gene; restriction enzyme

Received: 27/10/2020 , Accepted:20/12/2020

\section{INTRODUCTION}

One of the important nutritious diets is meat and meat products. Currently, meat production and consumption of numerous species is significantly increased in national as well as international markets. In a number of countries around the world, national and/or religious regulation confines the consumption of meat and meat products from certain species as a human food (Machovina et al., 2015). Since improper marking of animal foods may have remarkable negative consequences, authenticity of meat is currently subject of foremost worry for food authorities. In the previous few decades, meat and meat products debasement has become a problem in many nations (Malmheden and Emanuelsson, 1998). Due to public health, religious problems and harmful competition in the meat marketplace, the discovery of adulteration of meat has been a source of concern. Moreover, consumers have become more aware about the basis of meat and expect the source of meat to be reliable (Kumar et al., 2011 and Rashid et al., 2014).

The significant concern among meat consumers regarding the wholesomeness including safety and security traits of meat requires a number of studies to discover a method to distinguish meat adulteration which will have a huge influence on the economy as the consumers choice is significantly affected by the meat composition detailed in labeling (Henchion et al., 2017). Sensitive techniques are vital to detect different meat substances in order to assure correct labeling of meat. The meat production of beef (cattle 
and buffalo) is a serious matter in some religions. Further, the India government has allowed trade of buffalo only and not the cattle (Gundimeda and Ashwin, 2018). Therefore, food control laboratories it is an important task to determine species variation of fresh meats to be used for manufacturing meat equipment as well as the discovery of animal species in meat products (Vaithiyanathan and Kulkarni, 2016).

The techniques of PCR utilize specific worldwide primer random and/or specific primer to amplify target piece of DNA fragments (Mane et al., 2009). To identify the meat species, the traits of DNA patterns are useful. The technique of PCR assay is essential to detect the targeted single meat and meat production species (Arslan et al., 2005; Mane et al., 2009; Mane et al., 2012a; Mane et al., 2012b and Mane et al., 2012d). Nevertheless, RFLP-PCR technique plays a vital role to detect several sources of animal species with the help of digestion of the amplified DNA fragments by REs (Haider et al., 2012). Both PCR assays targets genomic and mitochondrial DNA techniques are used for meat species identification. Since there are not maternal effect of genomic DNA, so that the DNA samples do not matches with several allele combinations, this leads to raise the chance of getting satisfactory results of each tested samples, DNA mitochondria is more preferred than whole genomic for meat species identification (Greenwood and Paboo, 1999; Mane et al., 2012d; Mane et al., 2009; Mane et al., 2011; Partis et al., 2000 and Mane et al., 2014). The DNA (mtDNA) of mitochondria is the most generally investigated district of eukaryotic genomes which has assumed a basic job being developed of populace and evolutionary hereditary qualities (Abo-Hadeed et al., 2011 and DeMasi et al., 2015). The mitochondrial cytochrome $\mathrm{b}$ gene (cyt b) translates to a standout amongst the greatest recognized proteins that created the mitochondrial phosphorylation framework complex III and it is a single encoded by the mitochondrial genome (Kremer et al., 2017). The cyt b gene is utilized as a vital instrument in investigations of legitimate medication and molecular development (Kang'ethe et al., 1986; Koh et al., 1998; Prusak et al., 2004; AboHadeed et al., 2011; Cawthorn et al., 2013; Farag et al., 2015). A number of studies clearly showed that PCR technique offers both the specificity for adulteration detection and desired sensitivity of meat and meat products obtained from different species of animals (Hofmann, 1987; Girish et al., 2005; Zhang et al., 2007; Sahilah et al., 2011; De et al., 2011; Vaithiyanathan and Kulkarni, 2016). There is no research available for the species detection of imported buffalo meat in the Kurdistan region - Iraq. Thus, the present study aimed to recognize and find the exact origin species of the buffalo meat imported from Ukraine, Brazil and India to Erbil- Kurdistan region- Iraq by PCR-RFLP technique of the mitochondrial cytochrome $b$ gene.

\section{Sample preparation and DNA isolation}

\section{MATERIALS AND METHODS}

The present study was done on buffalo meat species which were imported from three countries Ukraine, Brazil and India to Erbil, in both molecular genetics laboratory in the college of agricultural engineering sciences and a private laboratory. Five buffalo meat samples were collected from each origin in four different markets of Erbil city, Iraq (total sample for each type $=20$ ).

Samples of meat were stored in aluminum foil at $-20^{\circ} \mathrm{C}$ for DNA extraction. BloodAnimal DNA Preparation Kit (Spin column based genomic DNA purification, Jena Bioscience GmbH, Germany) was used for DNA extraction of meat samples according to 
manufacture's procedure. Following extraction, the DNA was labeled and kept at $-20{ }^{\circ} \mathrm{C}$ until PCR examination. The purity of DNA was measured by Nanodrop spectrophotometer (UK) and gel electrophoresis. Purity of DNA ratio ranged between 1.7 and 1.9.

\section{Polymerase chain Reaction (PCR) Primers}

PCR occurred using a modification of the forced Restriction Fragment Length Polymorphism (RFLP) strategy. The primer sequences were F: 5'-CCA TCC AAC ATC TCA GCA TGA TGA AA-3' and R: 5'-GCC CCT CAG AAT GAT ATT TGT CCT CA3' which produce $359 \mathrm{bp}$ (the restriction site for the restriction enzymes used in this study for HinfI: 5'-G/ANTC-3' / 3' - CTNA/G-5', and for RsaI: 5' GT/AC-3' / 3'- CA/TG5')following procedure described by Khan et al. (2018).

\section{PCR Amplification}

The target DNA (mt Cytb gene, forward (L14841) and reverse (H15149) primers (NP_904340.1, gene ID: Gene ID: 17711) for each species was amplified by PCR (Applied Biosystems ${ }^{\circledR}$ Veriti ${ }^{\circledR}$ 96-Well Fast Thermal Cycler, USA). The final reaction volume for each one was of $25 \mu 1$, five $\mu 1$ of target DNA was added to each tube. An AMPLICON red Master Mix incorporates with $12.5 \mu \mathrm{l}$ Taq DNA polymerase (25Units/ml, dNTPs $200 \mu \mathrm{M}$, and $\mathrm{MgCl} 21.5 \mathrm{mM}$ ), $2 \mu 1 \mathrm{RFLP}$ primer (forward and revere), $5 \mu \mathrm{l}$ (50ng) of DNA template and $5.5 \mu 1$ DNase free water. The PCR program for the present study incorporated 35 cycles of starting denaturation for 5 minutes at $95 \mathrm{C}^{\circ}$ then normal denaturation took half a minute at the same temperature and annealing temperature was $50{ }^{\circ} \mathrm{C}$ for one minute the cycles ended with an extension stage at $72{ }^{\circ} \mathrm{C}$ for 0.45 minutes, then $72{ }^{\circ} \mathrm{C}$ for 7 minutes used in the final extension, after all, let the amplicons to Cool down at $4 \mathrm{c}^{\circ}$ until used in the next step. The products of PCR were screened in a $2 \%$ agarose gel having ethidium bromide (LOT: 110802BB197, Bio Basic Inc.) in buffer of Tris-borate EDTA and imaged under UV transillumination (Biostep-UST-20M-8K ).

\section{Analysis of RFLP}

The digestion of the PCR products was carried out using HinfI and Rsa I (ADR6201 00001211493, Promega- USA) restriction enzymes for each PCR product separately. The digestion mixture contained (10X Reaction buffer $2 \mu$ l, Reaction Enzyme 5 U, PCR product $10 \mu \mathrm{l}$ and filled with $7.5 \mu \mathrm{l}$ of free deionized water to make the final volume 20 $\mu 1)$, The digestion mixtures were incubated for $2-4$ hours at $\left(37^{\circ} \mathrm{C}\right)$ according to the restriction enzymes manufacture instructions. Ten $\mu l$ of the digested samples were taken, mixed with a loading buffer, and were electrophoresed via $2.5 \%$ agarose gel. The product of the restriction fragments size with digestion of RE were matched with one hundred bp DNA Ladder RTU stander (Cat NO. DM012-R500, Promega- USA).

\section{RESULTS AND DISCUSSION}

The mt cyt $b$ gene was positively amplified 359 bp clearly with no differences for each species after being separated by $2 \%$ agarose gel as shown in figure 1 . Following the amplicons were faced to HinfI and Rsa I restriction enzymes, both enzymes cleaved the target DNA in different places. Then, digested products were run on 3\% agarose gel electrophoresis. Each samples showed different fragment sizes after digestion when they were visualized under UV Transilluminator and recognized by the standard size marker comparison (Table 1 and Figure 2 and 3). 
Table (1): Number of bands and their sizes of imported buffalo meat in (Ukraine, Brazil and India) produced by digestion with (HinfI, RsaI) restriction enzymes.

\begin{tabular}{|c|c|c|}
\hline Imported meat & HinfI fragment size $\mathrm{pb}$ & RsaI fragment size $\mathrm{pb}$ \\
\hline Ukraine & 2 bands $(301,58)$ & 2 bands $(203,156)$ \\
\hline Brazil & 2 bands $(301,58)$ & 2 bands $(203,156)$ \\
\hline India & 2 bands $(274,85)$ & 2 bands $(253,106)$ \\
\hline
\end{tabular}

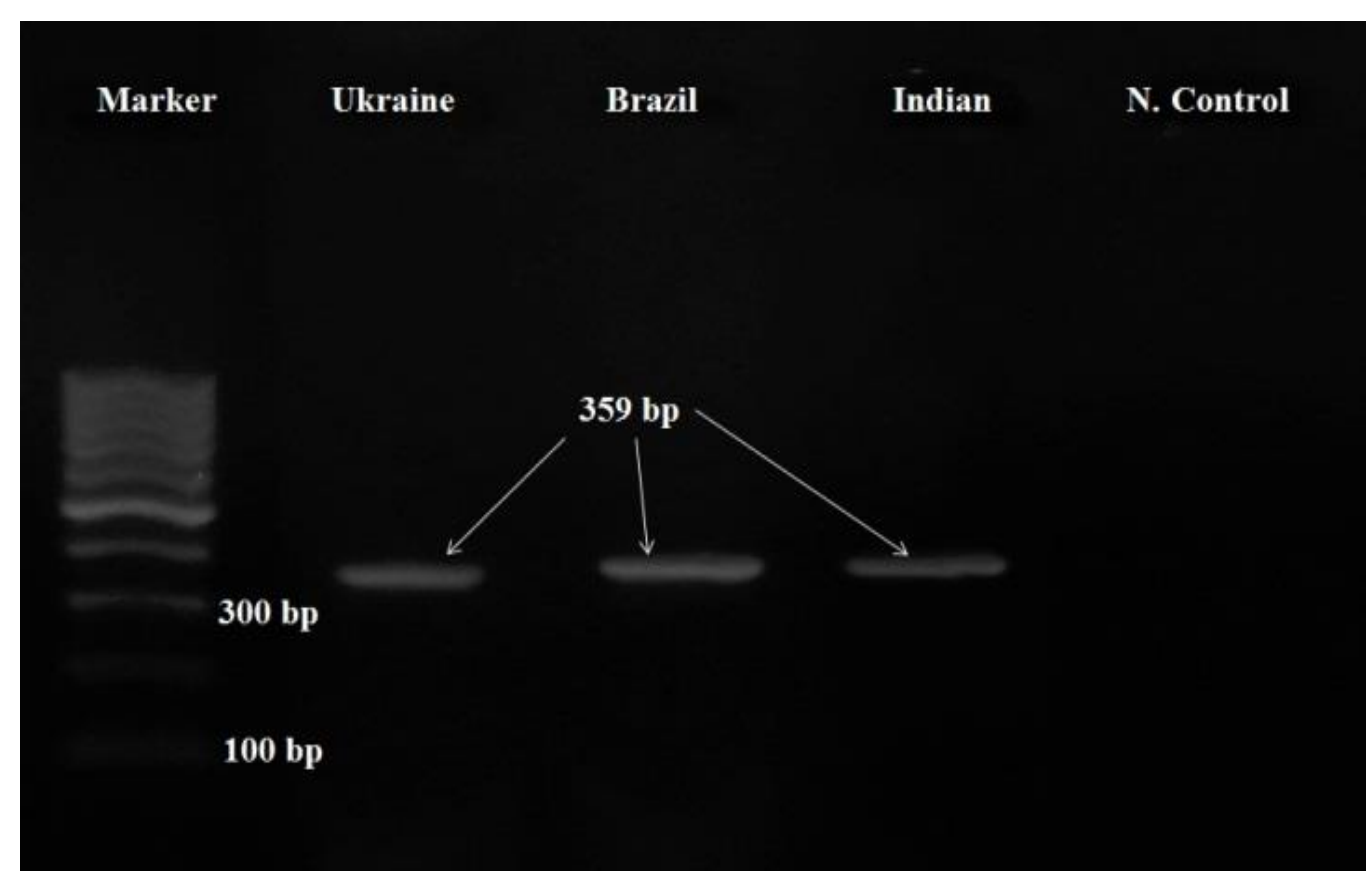

Figure (1): PCR product of three imported buffalo meat from (Ukraine, Brazil and India).

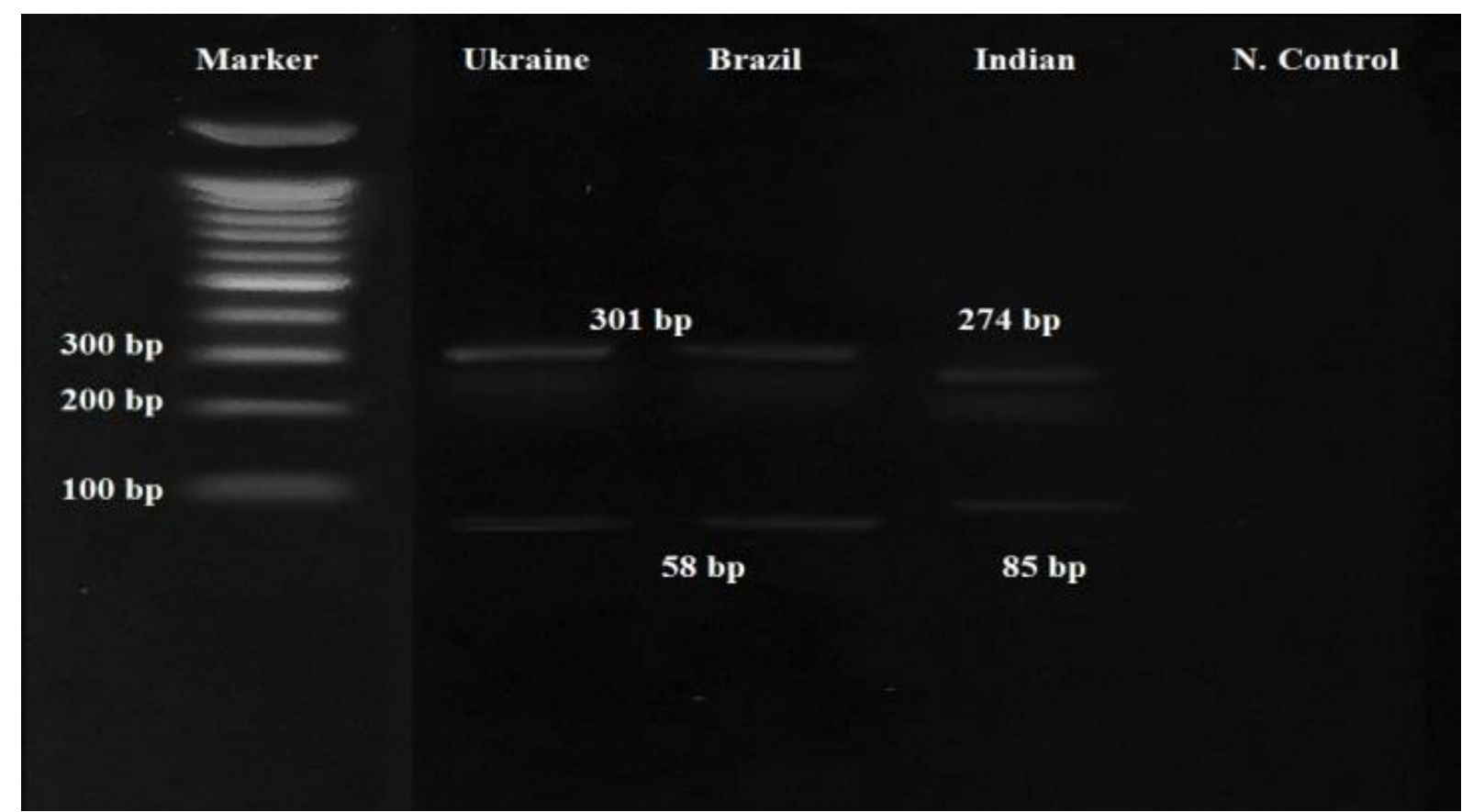

Figure (2): Digestion of PCR product of three imported buffalo meat from (Ukraine, Brazil and India) with HinfI restriction enzyme of Cyt B gene fragments. 


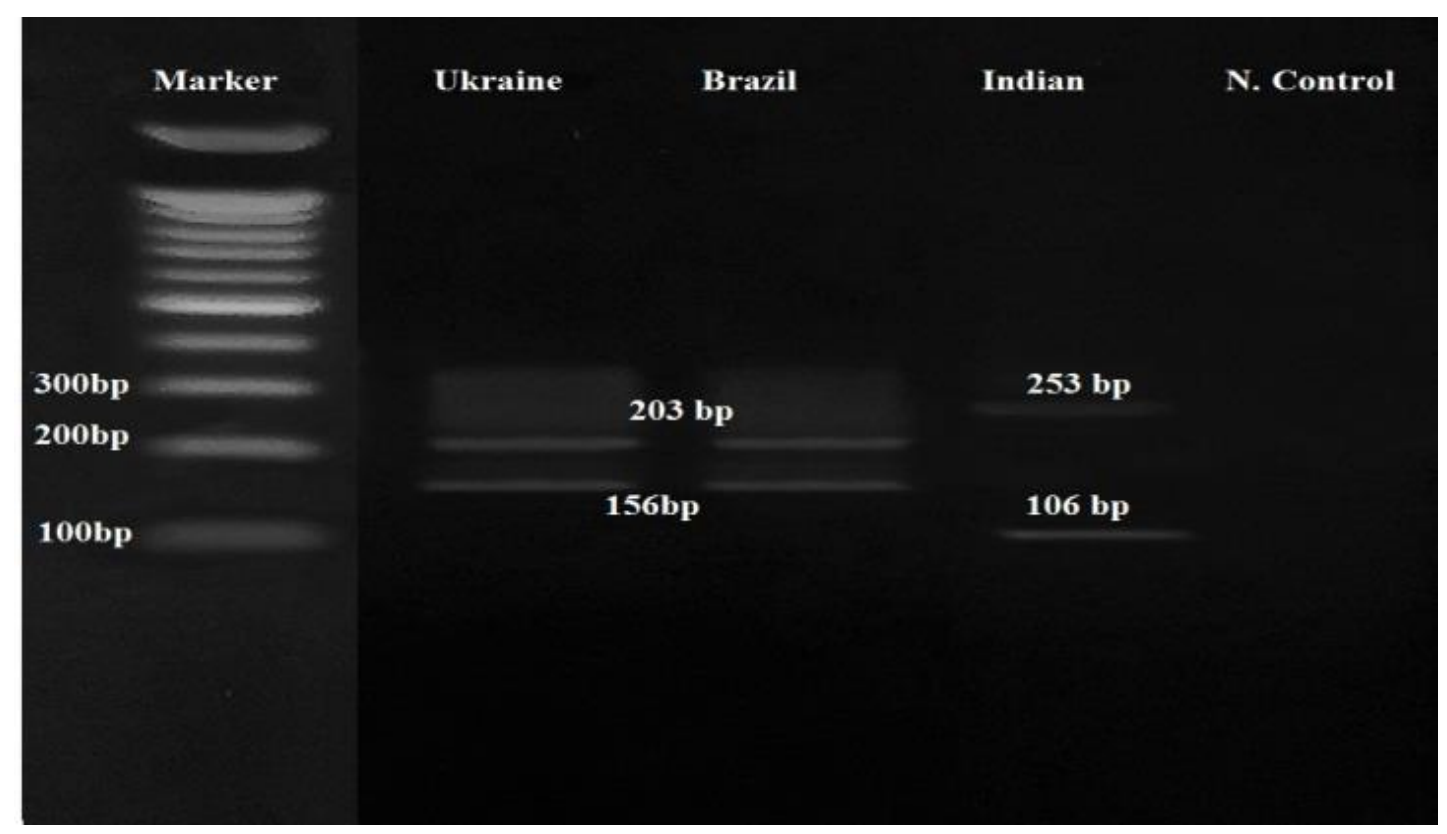

Figure (3): Digestion of PCR product of three imported buffalo meat from (Ukraine, Brazil and India) with RsaI restriction enzyme of Cyt B gene fragments.

Detection of meat and their products based on DNA identification methods always provide better determination and positive results compared with the other methods such as protein or traditional morphological identification. Therefore DNA based methods are the best valued method in order to identify commercial foods and animal products of origin species (Ali et al., 2015; Andrea et al., 2015).

In this century, adulteration or deception in meat has become a common, so that it is critical getting confirmation on the meat authentication to discover the species that is an origin in such products, since it is a vital for food safety, consumer demands, countries 'laws and ...etc., therefore seeking to identify the precise of meat origin became a significant part in procedures of meat quality control especially in poor countries (Farag et al., 2015; Khan et al., 2018).

According to the results of banding patterns for both restriction enzymes which were done at same time and samples together individually, we can notice that the Indian buffalo meat was shown mislabeling and described as fraudulent. Although it was labeled as a buffalo meat and there was probably another meat species which may be substituted with buffalo species before imported or may be occur after imported meat by the importers and suppliers, that must make clear for humans health and their interests for the exact species.

Analyzing the mt cyt $b$ gene region by PCR_RFLP method revealed excellent power and effective, tool for differentiating all imported buffalo meat species samples such as (Ukraine, Brazil and Indian) because there were no any unspecific bands or fragments produced when digested with restriction enzymes among them. Thus, restriction enzymes presented precise bands for each sample and there was no need to use statistical analysis to detect significant or insignificant among samples.

Researcher exemplified that fraudulent meat can be done during a variety of meat processing. Food particularly meat of two or more species can be mixed together or replacement of meat with substance that is cheaper or less acceptable quality (Khan et al., 2018). In such cases discrimination for the origin species and the multiple samples must 
be kept by the very sensitive methods such as RFLP - PCR, which detect a trace of meat mixtures (Khan et al., 2018). The results were attained in utilizing these two restriction enzymes were informed us that obtained results were acceptable and valid to authenticity and show a fraud meat and proposed to use other species to identify the real Indian buffalo species (Khan et al., 2018). Similar results in admixed heat treated meat products were reported by Girish et al. (2005).

Nagata et al. (2005) has also used PCR-RFLP of cyt b gene to identify wild animals with HinfI enzymes. The authors (Nagata et al., 2005) indicated that the technique seemed to create easily unique variances in banding patterns of RFLP among different species of wild animals. Their results (Nagata et al., 2005) were compatible with the present study results in terms of following enzyme of HinfI for detection of meat obtained for different animal species. Meat fraudulent has increased in many poor countries, for this reason identification and it is a vital to make the fraud products clear for the public or mislabeling products which cannot be observed with touching or sensing organisms, subsequently it is reflected significantly for food safety, consumer demands, laws and so on. For these using PCR based method RFLP-PCR technique with mitochondria cytochrome B gene is a very trustworthy method of the detection of origin meat species (Mane et al., 2009). The exceedingly preserved of mtDNA in various species of animals created an appropriate design of common primers for PCR essay (Ivona et al., 2016; Keyvan et al., 2017). This variability could be as a result of change in mitochondrial gene sequences which is tenfold higher in comparison with the whole genome (Unseld et al., 1995).

\section{CONCLUSION}

In conclusion, universal primers and conventional PCR using RFLP-PCR are a consistent and fundamental method through using two restriction enzymes (HinfI and RsaI) as well as can be given a very trustworthy result regarding identification of the species of buffalo meat imported from Ukraine, Brazil and India to Kurdistan region Iraq. Additionally, PCR - RFLP is a faster and cheaper method. The results of the present study clearly showed that there was some problem in the imported buffalo meat. According to the PCR -RFLP results imported Indian buffalo meat did not follow the rules and it neglected the public health and low, because it is available in markets as a buffalo meat. A fake or cheat product in many countries is a hazard. Therefore, justification is a must. To save good health and escape from fraud products, they usually must be examined by governmental organizations.

\section{ACKNOWLEDGMENTS}

The authors are very grateful to the Salahaddin University-Erbil for supporting this research.

\section{DISCLOSURE STATEMENT}

The authors declare that they have no conflicts of interest. 
تقنية تعدد أطوال جزء الحصر -تفاعل البوليميريز المتسلسل لتحديد أصل أنواع لحوم الجاموس المستوردة

\title{
الخلاصة
}

تهدف الدراســة الحالية الى تحديد أصـلـ الأنواع للحم الجاموس المســورد من ثلاثة بلدان (أوكرانيا ، البرازيل والهند) الى أربيل بتطبيق تقنية PCR-RFLP. تم اسـتخدام البادئ المعروف عالميا cyt b لتضــخيم قطعة 359 bp DNA Rsa I و للحصــول على خصـائص أشـكال الروابط في 2\% من الترحيل الكهربائي بالهلام (agarose)

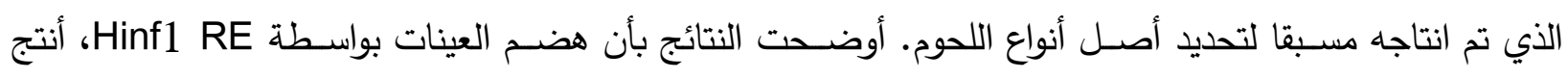
قطعتين DNA في لحم الجاموس المسـتورد من اوكرانيا والبرازيل، (58 و 301 (bp ) بينما أظهرت قطعة مختلفة في لحم الجاموس الهندي (85 و 274 bp ومن جهة أخرى فقد كانت النتائج باســـتخدام Rsa I RE رابطتين

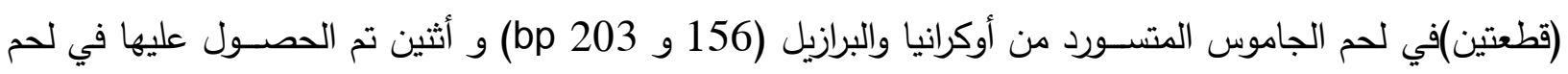
الجاموس الهندي (106 و 253 bp). من نتائج هذه الدراسة تم الوصول الى ان لحم الجاموس الهندي لم يكن مقبولا

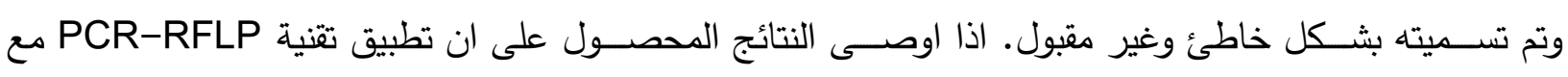
الأنزيمات القاطعة Hinf1 و Rsa I يلعب دورا مهما في الكشف اصل الانواع اللحم, لانه هذا التقنية طريقة سريعة , بسيطة و سهولة الاستخدام للتشخيص النوعية اللحم. الكلمات المفتاحية: لحوم جاموس مســتوردة، تحديد منتجات اللحم، الجين مايتوكوندريا ســايتوكروم بي، الانزيمات القاطعة

تاريخ استلام البحث / / / 2020 وقبوله: / / 2020

\section{REFERENCES}

Abo-Hadeed, A. H.; H. G. Mervat and R. F. Mayada (2011). Species identification of some non-domestic animals using PCR-RFLP analysis of cytochrome b gene. Zagazig Veternary Journal. 39(4): 37-46.

Ali, E, Abdur, R., Sharifah, B.A., Mahfujur, R., Al Amin, Abd Rashid A.J., \& Asing N.R. (2015). Multiplex PCR assay for the detection of five meat species forbidden in Islamic foods. Food Chemistry, 177(15): 214-224.

Andrea, A., Lisa, G., Lorenzo, C., Priscilla, D., Antonino, M., Renato, M., Daniela, G. and Alessandra, G. (2015). DNA and Mini-DNA barcoding for the identificationof Porgies species (family Sparidae) of commercial interest on the international market. Food Control, 50: 589-596.

Arslan, A.; I. Ilhak; M. Calicioglu and M. Karahan (2005). Identification of Meats Using Random Amplified Polymorphic DNA (RAPD) Technique. Journal of Muscle Foods. 16: 37-45. 
Cawthorn, D.; H. A. Steinman and L. C. Hoffman (2013). A high incidence of species substitution and mislabelling detected in meat products sold in South Africa. Food Control. 32: 440-449.

De, S; B. Brahma; S. Polley; A. Mukherjee; D. Banerjee; M. Gohaina; K. P. Singh; R. Singh; T. K. Datta and S. L. Goswami (2011). Simplex and duplex PCR assays for species specific identification of cattle and buffalo milk and cheese. Food Control. 22:690-696.

DeMasi, L; M. G. Adelfi; D. Pignone; and B. Laratta (2015). Identification of doris verrucosamolluscv mitochondrial $16 \mathrm{~S}$ rDNA. Biochemical Systematics and Ecology. 58: 21-29.

Farag, M. R; T. S. Imam and K. Dhama (2015) Identification of some domestic animal species (camel, buffalo and sheep) by PCR-RFLP analysis of the mitochondrial cytochrome b gene. Advanced Animal Veterinary Science. 3(2): 136-142.

Girish P. S; A. S. R. Anjaneyulu; K. N. Viswas; B. M. Shivakumar; M. Anand and M., Patel (2005). Meat species identification by Polymerase Chain Reaction-Restriction Fragment Length Polymorphism (PCR RFLP) of mitochondrial 12S rRNA gene. Meat Science. 0: 107-112. 7

Greenwood, A and S. Paboo (1999). Nuclear insertion sequences of mitochondrial DNA predominate in hair but not in blood of elephants. Molecular Ecology. 8: 133-137.

Gundimeda, S. and V.S. Ashwin (2018). Cow protection in India: From secularising to legitimating debates. South Asia Research. 38(2): 156-176.

Haider, N; I. Nabulsi and B. Al Safadi (2012). Identification of meat species by PCR RFLP of the mitochondrial COI gene. Meat Science. 90: 490- 493.

Henchion, M.M., M. McCarthy and V.C. Resconi (2017). Beef quality attributes: A systematic review of consumer perspectives. Meat science. 128: 1-7.

Hofmann, K (1987). Fundemental problems in identifying the animal species of muscle meat using electrophoretic methods. Fleischwirtshaft international. 67: 820-826.

Ivona, D. K; S. Danijela; M.Vladimir; R.Žarko;V. Dragutin and K. Goran (2016). Efficiency of PCR-RFLP and species-specific PCR for the identification of meat origin in dry sausages. Czech Journal of Food Science. 35: 386-391.

Kang'ethe, E. K; J. M. Gathuma and K. J. Landqvist (1986). Identification of the species of origin of fresh, cooked and canned meat on meat products using antisera to thermostable muscle antigens by Ouctherlony's double diffusion test. Journal of the Science Food and Agriculture. 37: 157-162.

Keyvan, E.; C. G. İplikçioğlu; K. B. Çinar; N. Bilgen and U. T. Şireli (2017). Identification of meat species in different types of meat products by PCR. Ankara Üniversitesi Veteriner Fakultesi Dergisi Journal. 64: 261-266.

Khan, W. A.; M. Hamid; A. Umara;, Y. Maimoona; A. Adeela; M. Khalid and I.Muhammad (2018). Identification of species-specific molecular markers in different farm animals by PCR-RFLP analysis. Pure and Applied Biology. 7 (1): 338-342.

Koh, M. C; C. H. Lim; S. B. Chua; S. T. Chew and S. T. W. Phang (1998). Random amplified polymorhic DNA (RAPD) fingerprints for identification of red meat animal species. Meat Science. 48, (3/4): 275-2859. 
Mesopotamia J. of Agric. Vol. (48) No. (4) 2020
ISSN: $2224-9796($ Online)

ISSN: 1815 - $316 \mathrm{X}$ (Print)

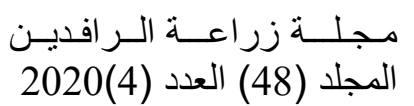

Kremer, L.S., D.M. Bader, C. Mertes, R. Kopajtich, G. Pichler, A. Iuso, T.B. Haack, E. Graf, T. Schwarzmayr, C. Terrile and E. Koňaříková (2017). Genetic diagnosis of mendelian disorders via RNA sequencing. Nature communications. 8(1): 1-11.

Kumar, D; S. P. Singh; K. V. Nagappa and A. Gaurav (2011). Identification of buffalo (Bubalus bubalis) meat using PCR targeting mitochondrial d-loop gene. Buffalo Bulletin. 30 (3): 170-176.

Machovina, B., K.J. Feeley, and W.J. Ripple (2015). Biodiversity conservation: The key is reducing meat consumption. Science of the Total Environment, 536: 419-431.

Malmheden, Y. I and R. Emanuelsson (1998). New Technology for Faster Disclosure of Meat Adulteration. Var Fada. 3: 6-7 (in Swedish).

Mane, B.G; S.K. Mendiratta and A.K. Tiwari (2009). PCR assay for specific identification of chicken species in meat and meat products. Food Chemistry. 116: 806-810.

Mane, B.G; S.K. Mendiratta and A.K. Tiwari (2012a). Beef specific polymerase chain reaction assay for authentication of meat and meat products. Food Control. 28: 246249.

Mane, B.G; S.K. Mendiratta and A.K. Tiwari (2014). PCR-RFLP assay for identification of species origin of meat and meat products .Journal of meat science and technology. 2(3): 31-36.

Mane, B.G; S.K. Mendiratta; A.K. Tiwari and A.A. Raut (2012b). Identification of chicken meat by means of polymerase chain reaction assay processed under different conditions. Indian Veterinary Journal. 89: 47- 48.

Mane, B.G; S.K. Mendiratta; A.K. Tiwari and R. Narayan (2012d). A novel approach for simultaneous differentiation of closely related meat species by PCR assay using single primer pair. Indian Journal of Animal Science. 82: 1570-1573.

Mane, B.G; S.K. Mendiratta; A.K. Tiwari; B..D. Sharma; K.N. Bhilegaokar and A.S.R Anjaneyulu (2011). Detection of pork in admixed meat and meat products by species specific PCR technique. Indian Journal of Animal Science. 81: 1178-1181.

Mane, B.G; V.K, Tanwar; P.S. Girish; D Sharma and V.P. Dixit (2008). RAPD markers for differentiation of meat species. Indian Journal of Veterinary Research. 17(2): 9-13.

Nagata, J; V.V. Aramilev; A. Belozor; T. Sugimoto and D.R. McCullough (2005). Fecal genetic analysis using PCR-RFLP of cytochrome b to identify sympatric carnivores, the tiger pantheratigris and leopard pantherapardus, in far eastern Russia. Conservative Genent. 6(5): 863-865.

Partis, L; D. Croan; Z. Guo; R. Clark; T. Coldham and J. Murby (2000). Evaluation of a DNA fingerprinting method for determining the species origin of meats. Meat Science. 54: 369-376.

Prusak, B; G. Grzybowski and G. Zieba (2004). Taxonomic position of bison bison (Linnaeus, 1758) and bison bonasus (Linnaeus, 1758) based on analysis of cyt b gene. Animal Science Paper and Report. 22(1): 27-35.

Rashid, P. M; M. O., Babashekh; A. S. Marouf and K.M. Amin (2014). Identification of animal species in meat broth by simplex and multiplex PCR. Journal of Zankoy Sulaimani- Part A. 6(1): 197-102.

Saez, R; Y. Sanz and F. Toldra (2004). PCR based fingerprinting techniques for rapid detection of animal species in meat products. Meat Science. 66: 659- 665. 
Sahilah, A.M; Y, Norhayati; W.M, Wan Aida and A. Aminah (2011). Halal authentication of raw meats using PCR amplification of mitochondrial DNA. International Food Resources Journal. 18:1489-1491.

Unseld, M; B. Beyerman; P. Brandt and, R. Hiesel (1995). Identification of the species origin in highly processed meat products by mitochondrial DNA sequences PCR Methods and Applications. 5: 241-243.

Vaithiyanathan, S and V. V. Kulkarni (2016). Species identification of cattle and buffalo fat through PCR assay. Journal of meat science and technology. 53(4): 2077-2082.

Zhang, C; M.R. Fowler; N.W. Scott; G. Lawson; A. Slater (2007). A TaqMan real-time PCR system for the identification and quantification of bovine DNA in meats, milks and cheeses. Food Control. 18:1149-1158. 